\title{
Tracer Study of 2019 Graduates of Holeta Polytechnic College in the Catchment Area
}

\author{
Agro-Processing Department, Holeta Polytechnic College, Holeta, Ethiopia \\ Email address: \\ tftamiruf@gmail.com (T. Fufa), efagobena@gmail.com (E. Gobena) \\ ${ }^{*}$ Corresponding author
}

Tamiru Fufa ${ }^{*}$, Markos Zelalem, Gemechu Feyisa, Teferi Daba, Efa Gobena

\section{To cite this article:}

Tamiru Fufa, Markos Zelalem, Gemechu Feyisa, Teferi Daba, Efa Gobena. Tracer Study of 2019 Graduates of Holeta Polytechnic College in the Catchment Area. International Journal of Secondary Education. Vol. 6, No. 4, 2021, pp. 99-111. doi: 10.11648/j.ijecs.20210604.12

Received: May 25, 2021; Accepted: July 8, 2021; Published: July 15, 2021

\begin{abstract}
A purpose-driven and effective TVET is basic to generate competent and essential high-level skills, values, and knowledge vital for the socio-economic development of a country. The study traced the HPC students who graduated in 2011 in terms of their job placement profile and the usefulness, relevance, and adequacy of the skills and competencies as well as work-related values to their job placement. A survey method using questionnaire was utilized to 229 respondents. Results revealed that most of the respondents didn't landed on jobs which were related to their training program for about 1-6 months. The total number 2019 graduates employed in these organization were 45 out of which 42 graduates 50\% (21) were employed on the related position where as $50 \%$ (21) were employed to the position which is irrelevant to their field of study. The remaining $6.7 \%$ did not respond. These employed graduates are from 7 different colleges and one TVET center. The occupation they have been specialized in are 9. Out of 51 graduates found in Holeta and Walmara district only 14 unemployed graduates filled the survey questionnaires $14.3 \%$ (2) continued their degree program while other are still searching for the job. The study revealed that lack of experience, existing bureaucracy, saturation of the occupation of the graduate's main obstacles to get jobs. Finally, as one aspect in the sustainability it will be crucial to identify ways to further publish and disseminate the tracer study results, in order to make them a regular, visible steering tool for both TVET institutes at the local level as well as at the national level.
\end{abstract}

Keywords: Tracer Study, Holeta, Graduates

\section{Introduction}

Holeta Polytechnic College is planning to establish a Center of Excellence in Agro-Processing (CEAP) through the East Africa Skills for Transformation and Regional Integration Project (EASTRIP) funded by the World Bank (WB). The overall objective of the proposed CEAP at Holeta Polytechnic College is to deliver quality outcome-based training and to supply competent, motivated and innovative middle and low-level workforce equipped with the necessary technological skills that would ensure the implementation of an agriculture-led industrial economy of Ethiopia. Towards the end of the 20th Century, European Universities embraced the use of tracer studies for a plethora of reasons; especially to accredit their study programs; to explain the link between study programs and the job market; to show uniqueness and positioning of individual universities; and also to enable universities and institutions managing higher education in their respective countries make informed and evidence based decisions about improvements and quality education and services in higher education [2, 4]. East Africa (EA) universities and higher education institutions (HEIs) should not be an exception. In addition, importance of graduate tracer studies is to incorporate effective improvements into institutional programs of HEIs by collecting and analyzing information on graduate's study experiences, professional and personal careers. Such studies can be used to collect data on the employment situation of the most recent graduates in order to obtain indicators for their professional performance [5]. They can therefore, be used to contribute to causal explanations of the relevance and appropriateness of the study conditions, services and programmes provided by HEIs and the quality of the graduate product [6-8].

Tracer study is an important tool to obtain valuable 
information regarding the graduates' livelihood after they completed their training and join the labor market [3]. This information will be used for minimizing any possible deficits in the program and improve it for the future in terms of content, quality and delivery of the training and creating employment opportunities. In contrast to such elite systems, higher education (HE) systems across the world have become increasingly massified in recent years [14]. Massification connotes more than a simple, albeit substantial, expansion of student numbers [15].

Tracer studies are widespread in higher education but also often employed in the VET (vocational education and training) / TVET (technical vocational education and training) (2) sector. In many countries, conducting tracer studies is a formal requirement for the accreditation of study programs. Programs/projects seeking reform of TVET, which try to improve skills match and the transition from school to work, use data from tracer studies to measure their effectiveness. Education institutions are also increasingly interested in feedback from their former students to improve their study programs, and to show new applicants how their graduates have managed the transition to employment.

The tracer study manual [10] states that the primary purpose of a tracer survey is to assess whether TVET graduates, are able to get gainful employment or not, be it wage employment or self-employment. In effect while a tracer survey, as the name implies, is tracing where about of graduates, it is also an important mechanism to assess how effective and efficient training centers are in meeting their objectives; that is, in preparing young people for the next phase of their lives through providing quality training.

Many countries are experiencing growing demand to introduce a system of tracer studies due to requirements of reaccreditations and quality management. Education institutions are often forced by law to implement regular tracer studies, and demand from various donor agencies or stakeholders (such as the World Bank, EU, Asian Development Bank and the national agencies) to collect empirical evidence about the relevance of the education/training is also growing. HEIs today are increasingly viewed as central to national strategies for securing shares in the global market and universities as the repositories of valuable human capital to support the economic development of the nation. Universities are in that favored position of keeping and creating science. Graduates occupy an interesting position in the economy and there are still competing interpretations about the outcomes of graduates when they enter the labor market [11-13]. [1] Study conducted on tracer study which was forced by Ethiopia government to conduct tracer study and evaluate the employability of graduates for each program undertaken in institution. After the tracer study conducted the institution decided on the continuity of the program going on in the institution or closing the program. Therefore, HPC tracer study is intended to generate information on the employment status and conditions of youth who were trained in HPC. It also aimed at generating information on the competitiveness of HPC graduates and employment destinations.

\subsection{Research Objectives}

\subsubsection{General Objective}

The primary objective is to measure the relevance of technical and vocational training programs and the number of trainees who have been employed or unemployed in their fields of training, as well as to assess their skill gaps for further training.

\subsubsection{Specific Objectives}

To provide the HPC catchment area with practical and hands-on information on the employment status of TVET graduates in the labor market.

To assess the skills gap and training needs of the TVET graduates.

To know the number of trainees finding employment on the field of occupations they had been trained.

To asses why unemployed trainee graduates could not be able to find employment in the labor market.

\subsection{Limitation of the Study}

The accessibility of all graduates in the study catchment area as well as graduates of the Colleges became difficulty due to lack of data sources and malfunction of registered phone number obviously affecting to study the whole graduates. As illustrated under study area particularly graduates of HPC came from 7 Zones and 3 Towns which is very wide area to get in touch all graduates during the study.

\section{Methodology}

\subsection{Study Area}

The study area is predetermined by government based on TVET Cluster Structure. The catchment area covers Holeta Town and Wolmera District. Such tracer believed to be conducted by other TVET Institutions according to their cluster. Thus, the study is restricted to this catchment area.

\subsection{Employers of HPC Graduates}

The list of all private enterprises was taken from Investment of Offices of both local administrations' bodies (Holeta Town administration and Walmera district Administration) and enterprises have capacities of employing were purposely selected to be studied. All Federal and local organizations found in the catchment areas were studied.

\subsection{Baseline Survey of 2019 Graduates}

For the base line survey, the whole graduates of 2019 (142 male and 87 female totals of 229) were studied based on the guidance of tracer study manual.

\subsection{Employed Graduates of 2019}

Through phone contacts it was tried to call 238 HPTC graduates using their personal phone or family's phone. The 
survey of all other employed HPC graduates were conducted in all potential employer organizations. Only 45 were found in 31 organizations.

\subsection{Unemployed Graduates}

The study on unemployed graduates was limited to graduates of HPC which were found in the study catchment area. Number of HPC Graduates were 51 of which 39 are living in Holeta Town whereas 12 are living in Walmara District. Out of these 51 graduates, 16 have been already employed and, 12 unemployed graduates of HPC were surveyed, the phone of 13 was not working, 6 graduates did not respond, the phone of 4 respondents were wrong. In general, only 12 unemployed graduates able to fill questionnaires.

\section{Presentation and Discussion of Results}

This part is concerned with the analysis and interpretation of data collected through survey questionnaires and document analysis. This part of presents the findings of 229 base line survey of 2019 graduates, field survey of 31 employer organization who already employed TVET Graduates, 45 graduate who has got paid employment and 12 unemployed graduates. The analysis dealt with information gathered through questionnaire filled using telephone call for 12 unemployed graduates and from employer organization and from employed graduates the questionnaires distributed directly. The collected data was analyzed using IBM SPSS Statistics 21 computer software.

\subsection{Baseline Survey of 2019 Graduates}

\subsubsection{Spatial Distribution of Graduates}

Graduates of 2019 came from 3 Towns (namely Hoolataa, Amboo and Sulultaa) and 7 Zones (namely, East Walaga, Horro Guduru Walaga, Kelem Walaga, North Shawa, South West Shawa, Special Zone of Oromia Surrounding Finfinne and West Shawa). The survey data show that $66.4 \%, 17.5 \%$ and $6.6 \%$ graduates came from West Shawa Zone, Holeta Town and North Shawa respectively. Thus, Holeta town and the two zones account for more than 90\% of HPTC's 2019 graduates. Sululta Town, Kelem Wallaga and South West Shawa were each contributed only $0.4 \%$ trainees. When the number of graduates from town were compared to the number of graduates from rural area districts by far graduates from rural area is higher than that of from urban areas; i.e. $81.2 \%$ from Town vs. $18.8 \%$ from Rural districts. From 7 Zonal areas our customers came from 29 districts and 184 villages which shows that the high number of our customer were from rural areas and Gandaas. Concerning the social media utilization out of 229 respondents only $3.5 \%$ have Facebook account and $0.4 \%$ has email address whereas all have own cell phone.

\subsubsection{Socio Demographic Information}

Gender: Out of 229 graduates $62.01 \%$ were male whereas $37.99 \%$ were female. According to the data obtained the college registrar the number of female graduates was proportional to the male during registration (which is almost about $50 \%$ ). But the graduation rate of the students indicated that the graduation rate of females is lower than male. Based on the finding of this tracer study increasing the enrollment of the female students in to the college is not enough, due to after enrolled measures have to be taken to increase the female graduation. This needs further study in order to know the reason to come up with the possible solution.

Marital status: The survey result of tracer study showed that from the total sample considered for this study about $95.30 \%$ of the graduates were single, $4.23 \%$ were married, and $0.47 \%$ was divorced which implied that large number of graduates are single.

Table 1. Demographics characteristics of respondents.

\begin{tabular}{llll}
\hline Variables & & Frequency & Percent \\
\hline \multirow{2}{*}{ Gender } & Male & 142 & 62.01 \\
& Female & 87 & 37.99 \\
Marital status & Single & 203 & 95.30 \\
& Married & 9 & 4.23 \\
& Divorce & 1 & 0.47 \\
Age & $\leq 20$ & 98 & 43.56 .0 \\
& $21-25$ & 124 & 55.11 \\
& $26-30$ & 1 & 0.44 \\
& $30-35$ & 2 & 0.89 \\
\hline
\end{tabular}

Source: Surveyed data 2020

Age: It indicated that participants according to the study were mostly aging between 21 and 25 which account about $55.11 \%$ and around 43.56 was below 20 years old. This implied that out of the graduates more $50 \%$ of respondents was in the active labor force when they considered for jobs in different government and non-government organization. When our graduates were analyzed in terms of age, $98.6 \%$ were aged 25 years old or less which shows that they were potentially found at productive age.

\subsection{Educational Characteristics of Graduates}

Based on the occupational standard set the graduates sampled and the result of the qualification indicator illustrated in table 3 . The result showed about $35.52 \%$, $25.88 \%, 18.86 \%, 9.66 \%, 7.45 \%, 1.75 \%, 0.44 \%$ and $0.44 \%$, of HPTC graduates 2019 in NRCUM, AAHS, APMM, HNS, CPMM, ITSS, GAHC and HCCP are indicated percentages qualification respectively. As it is known Holeta polytechnic College giving different training programs the proportion of the graduates the showed as $97.4 \%$ is Level IV, $2.2 \%$ is Level II and $0.4 \%$ is level III. This implied that large number graduates were those completed level IV. When this proportion compared with the threshold of Moshe it doesn't coincide with the ratio set. The other indicator considered as measures of qualification is the number of the graduates passed the $\mathrm{CoC}$ and the $\mathrm{CoC}$ result showed that there are graduates not yet competent during trail 2 which in turns has also impact on the employability of the graduates. 


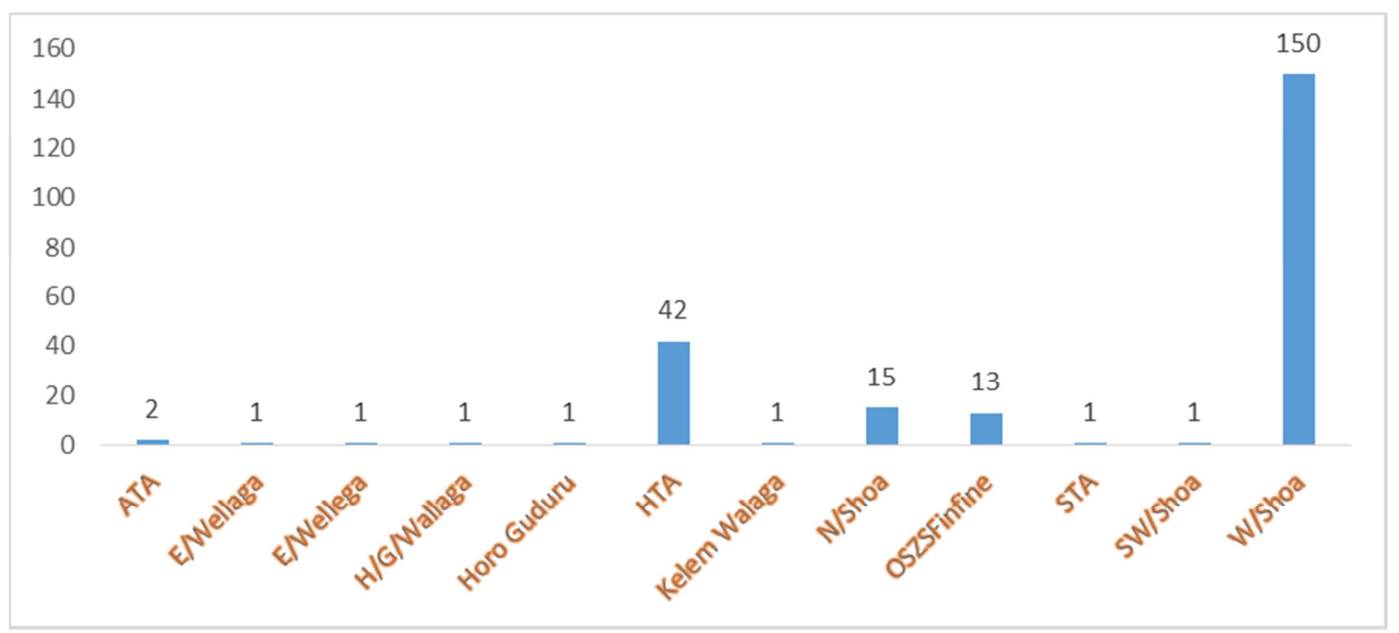

Source: Surveyed data 2020

Figure 1. Spatial distribution of 2019 graduates.

Table 2. Qualification of the respondents sampled.

\begin{tabular}{llll}
\hline Variables & & Frequency & Percent \\
\hline \multirow{5}{*}{ Qualification } & AAHS & 59 & 25.88 \\
& APMM & 43 & 18.86 \\
& CPMM & 17 & 7.45 \\
& GAHC & 1 & 0.44 \\
& HNS & 22 & 9.66 \\
& ITSS & 1 & 0.44 \\
& NRCUM & 4 & 1.75 \\
& Total & 81 & 35.52 \\
& Level II & 228 & 100 \\
& Level III & 5 & 2.2 \\
& Level IV & 1 & 0.4 \\
& Total & 223 & 97.4 \\
& No. of graduates NYC & 229 & 100 \\
& trail1 and 2 & 83 & 36.2 \\
CoC Result & Trail 1 (Jul2019) & 106 & 46.3 \\
& Trail 2 (Dec2019) & 40 & 17.5 \\
& Total & 229 & 100 \\
\hline
\end{tabular}

Source: Surveyed data 2020

\subsubsection{Delivery of Quality Training HPTC}

Currently Ethiopia ministry of education planned to taught the students as per their interest, even though the capacity of the institution in the country cannot allow to do so. The survey result showed about $97.66 \%$ of respondents of the graduates were trained according to their preference while around $2.34 \%$ were not trained as per their preferences. The remaining $6.6 \%$ did not responds. Obviously, most trainees could be motivated at large since their interest was maintained. But their COC result shows that only $46.6 \%$ were competent in the first trail and $17.5 \%$ in the second trail. The remaining $36.2 \%$ were either didn't evaluated or still not yet competent. This This is a wastage for the government and the society hence it needs the attentions of all stakeholders in general and HPTC in particular in the future.

Table 3. Delivery of quality training for respondents.

\begin{tabular}{lll}
\hline & Frequency & Percent \\
\hline Yes & 209 & 97.66 \\
No & 5 & 2.34 \\
Total & 214 & 100.0 \\
\hline
\end{tabular}

Source: Surveyed data 2020

\subsubsection{The Contents of the Training}

In TVET, particularly in outcome-based training, quality training is the main thematic area (MoE, 2008). According to 2019 tracer study conducted in Holeta Polytechnic College above $50 \%$ of HPTC trainees showed dissatisfaction with the training delivered in the college due to many quality factors identified with action research undertaken to survey the factors affecting quality of training. The base line survey of 2019 graduates were also undertaken on 229 graduates with 13 quality measuring elements. Likert scale range from 1 to 5 was used to rate the value of each measuring element in which 5 represents strongly agree to high quality while 1 stands for strongly disagree. Averagely, the survey findings revealed that $65.56 \%$ of respondents were strongly agreed, $19.32 \%$ agreed, $6.78 \%$ neutral, $3.38 \%$ disagreed, strongly disagreed $3.39 \%$ while the remaining $1.64 \%$ didn't replied for the questionnaires. The result shows that almost $85 \%$ respondents were above average value (3). The respondents confirmed the quality trainings were delivered in the college which antagonized with result of action research undertaken by Tamiru et al., 2019 at HPTC. 


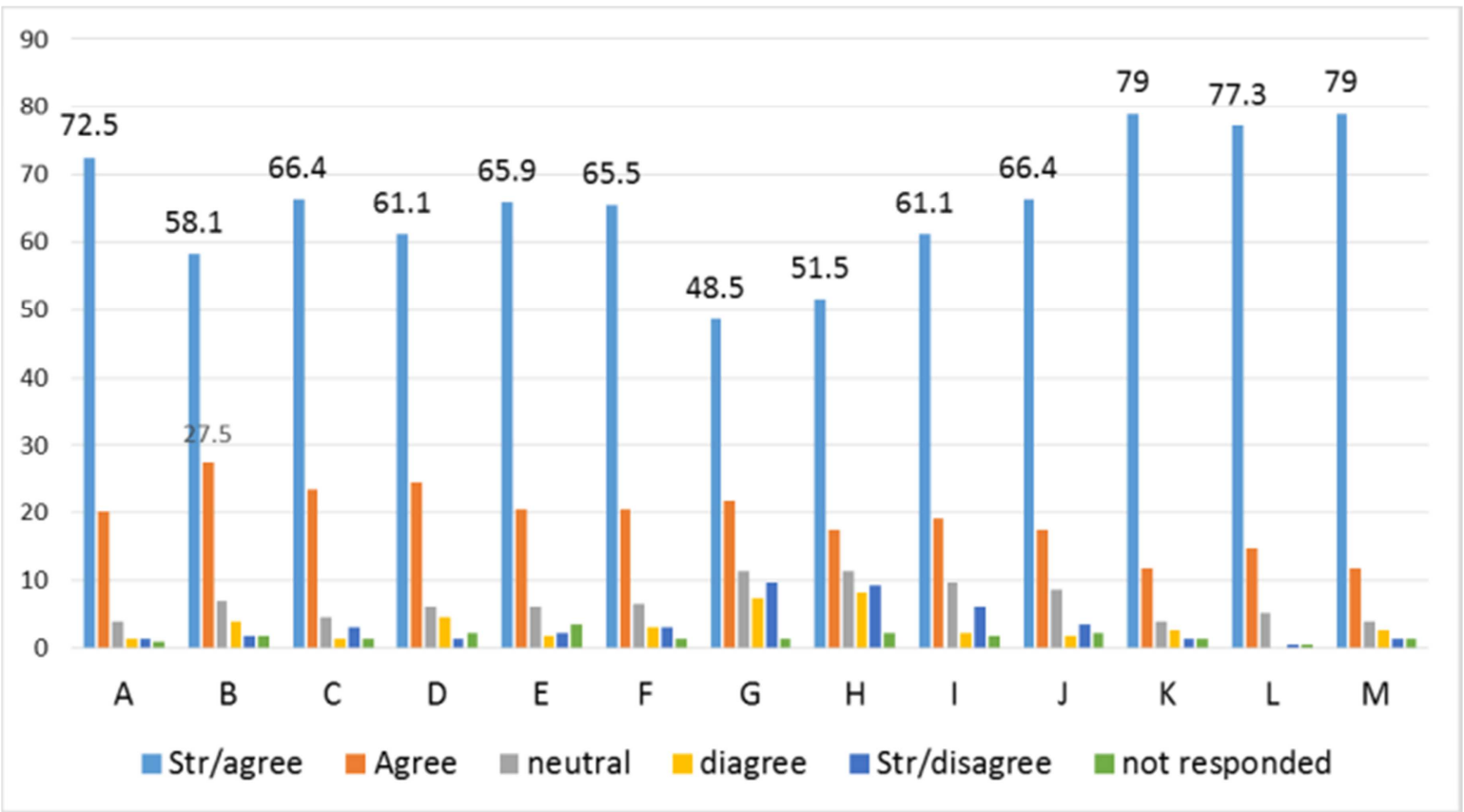

Source: Surveyed data, 2020

Figure 2. Contents of the training.

Table 4. Trainings contents in HPTC.

\begin{tabular}{|c|c|c|c|c|c|c|c|c|}
\hline \multicolumn{3}{|c|}{ Items } & \multirow{2}{*}{$\begin{array}{l}\text { Str/agree } \\
166\end{array}$} & \multirow{2}{*}{$\begin{array}{l}\text { Agree } \\
46\end{array}$} & \multirow{2}{*}{$\begin{array}{l}\text { neutral } \\
9\end{array}$} & \multirow{2}{*}{$\frac{\text { disagree }}{3}$} & \multirow{2}{*}{$\begin{array}{l}\text { Str/disagree } \\
3\end{array}$} & \multirow{2}{*}{$\frac{\text { not responded }}{2}$} \\
\hline$A$ & Objective was well explained in theoretical & Frequency & & & & & & \\
\hline $\mathrm{H}$ & training & Percent & 72.5 & 20.1 & 3.9 & 1.3 & 1.3 & .9 \\
\hline \multirow{2}{*}{ B } & Objective was well explained in practical & Frequency & 133 & 63 & 16 & 9 & 4 & 4 \\
\hline & trainings & Percent & 58.1 & 27.5 & 7.0 & 3.9 & 1.7 & 1.7 \\
\hline \multirow{2}{*}{$\mathrm{C}$} & Trainers are always well prepared in theory & Frequency & 152 & 54 & 10 & 3 & 7 & 3 \\
\hline & training & Percent & 66.4 & 23.6 & 4.4 & 1.3 & 3.1 & 1.3 \\
\hline \multirow{2}{*}{$\mathrm{D}$} & Trainers are always well prepared in practical & Frequency & 141 & 56 & 14 & 10 & 3 & 5 \\
\hline & trainings & Percent & 61.1 & 24.5 & 6.1 & 4.4 & 1.3 & 2.2 \\
\hline \multirow{2}{*}{ E } & & Frequency & 151 & 47 & 14 & 4 & 5 & 8 \\
\hline & Trainers were/are well qualified theoretically & Percent & 65.9 & 20.5 & 6.1 & 1.7 & 2.2 & 3.5 \\
\hline \multirow{2}{*}{$\mathrm{F}$} & Our trainers were well qualified to conduct & Frequency & 150 & 47 & 15 & 7 & 7 & 3 \\
\hline & practical trainings. & Percent & 65.5 & 20.5 & 6.6 & 3.1 & 3.1 & 1.3 \\
\hline \multirow{2}{*}{ G } & Training Materials and Equipment were/are & Frequency & 111 & 50 & 26 & 17 & 22 & 3 \\
\hline & adequate & Percent & 48.5 & 21.8 & 11.4 & 7.4 & 9.6 & 1.3 \\
\hline \multirow{2}{*}{$\mathrm{H}$} & Trainers prepared sufficient TTLM for & Frequency & 118 & 40 & 26 & 19 & 21 & 5 \\
\hline & practical trainings & Percent & 51.5 & 17.5 & 11.4 & 8.3 & 9.2 & 2.2 \\
\hline \multirow{2}{*}{ I } & Theoretical training was based on the world & Frequency & 140 & 44 & 22 & 5 & 14 & 4 \\
\hline & of work. & Percent & 61.1 & 19.2 & 9.6 & 2.2 & 6.1 & 1.7 \\
\hline \multirow{2}{*}{$\mathrm{J}$} & Practical training was clearly based on the & Frequency & 152 & 40 & 20 & 4 & 8 & 5 \\
\hline & reality of the world of work. & Percent & 66.4 & 17.5 & 8.7 & 1.7 & 3.5 & 2.2 \\
\hline \multirow{2}{*}{$\mathrm{K}$} & I acquired theoretical knowledge for my & Frequency & 181 & 27 & 9 & 6 & 3 & 3 \\
\hline & future job. & Percent & 79. & 11.8 & 3.9 & 2.6 & 1.3 & 1.3 \\
\hline \multirow{2}{*}{$\mathrm{L}$} & I acquired practical skill for my future job. & Frequency & 177 & 34 & 12 & 3 & 2 & 1 \\
\hline & 1 acquired practical skill for my future job. & Percent & 77.3 & 14.8 & 5.2 & 0,9 & 0.4 & 0.4 \\
\hline & Linkage between theoretical and practical & Frequency & 181 & 27 & 9 & 6 & 3 & 3 \\
\hline & training & Percent & 79 & 11.8 & 3.9 & 2.6 & 1.3 & 1.3 \\
\hline \multicolumn{2}{|c|}{ Average $\%$} & & 65.56 & 19.32 & 6.78 & 3.38 & 3.39 & 1.64 \\
\hline
\end{tabular}

Source: Surveyed data 2020

The opinion of the trainers was assessed to check what was/were lacking during their training time stay in the college. Training methodology, project-based training, commitment of traininer and others affect the quality of the education. Staff and training materials/equipment were used as measuring parameters. The parameters were rated based on Likert scale with 1 to 5 value: 5 being the shortage is very high and 1 is no weakness at all. With this scale $35.81 \%$ is above neutral at an average which shows that in line with these parameters significant percentage of respondents replied that the shortage is rated either very high or high. About $53.17 \%$ are below neutral which is in this case the 
shortages are either low or not existing at all.

Table 5. Problem of delivering quality training.

\begin{tabular}{|c|c|c|c|c|c|c|c|}
\hline & & Missed & very high & High & neutral & Low & no weakness at all \\
\hline \multirow{2}{*}{ Training methodology } & Frequency & 5 & 13 & 52 & 10 & 106 & 43 \\
\hline & Percent & 2.18 & 5.68 & 22.70 & 4.37 & 46.29 & 18.78 \\
\hline \multirow{2}{*}{ Project based training } & Frequency & 5 & 24 & 65 & 23 & 69 & 43 \\
\hline & Percent & 2.18 & 10.48 & 28.38 & 10.04 & 30.13 & 18.78 \\
\hline \multirow{2}{*}{ Commitment of training staff } & Frequency & 6 & 32 & 59 & 21 & 60 & 51 \\
\hline & Percent & 2.62 & 13.97 & 25.76 & 9.17 & 26.20 & 22.27 \\
\hline Training materials/equipment & Frequency & 7 & 28 & 55 & 24 & 73 & 42 \\
\hline
\end{tabular}

Source: Surveyed data 2020

Table 6. Cooperative training.

\begin{tabular}{lll}
\hline Variables & Frequency & Percent \\
\hline Yes & 158 & 71.81 \\
No & 62 & 28.19 \\
Total & 220 & 100.0 \\
\hline
\end{tabular}

Source: Surveyed data 2020

\subsubsection{Cooperative Training}

Cooperative training is considered as one of the main training modes that is needed to be implemented in OBT training in order to achieve the required quality trainings in collaboration with industries. In this study the implementation of cooperative training was examined using the survey questionnaire. The respondents were asked whether they participated in cooperative training or not for all units of competencies they had been trained; $71.81 \%$ confirmed that they participated in cooperative trainings while $28.19 \%$ did not.

Holeta Polytechnic College have been used different organization to undertake cooperative training. The organization such as Public enterprises, Private enterprises, Government Offices/Institutes, Micro enterprises and NonGovernmental Organizations as potential cooperative training centers question was posed for the graduates in order to know where they took cooperative trainings. Among 158 respondents those took cooperative training in all aforementioned organization were $25.32 \%$ (40), Public enterprises were $20.89 \%$ (33) government office institute were $12.66 \%$ (20). Specially, public enterprises were used as the highest cooperative training center either exclusively or with other organization. Among 158 respondents 114 $(72.15 \%)$ replied as public enterprises were the main cooperative training center.

Table 7. Organizations Center for Training Cooperative Training.

\begin{tabular}{|c|c|c|}
\hline Cooperative training centers & Freq. & Percent \\
\hline Public enterprise & 33 & 20.89 \\
\hline Public enterprise, privet enterprise & 3 & 1.90 \\
\hline Public enterprise, privet Enterprise, government office/institute & 3 & 1.90 \\
\hline Privet enterprise, government office/institute & 1 & 0.63 \\
\hline Public enterprise privet enterprise, government office/institute, micro enterprise & 2 & 1.27 \\
\hline Public enterprise, privet enterprise, government office/institute, micro enterprise, NGO & 40 & 25.32 \\
\hline Public enterprise privet enterprise, government office/institute, micro enterprise, NGO & 2 & 1.27 \\
\hline Public enterprise, privet enterprise, government office/institute, NGO & 1 & 0.63 \\
\hline Public enterprise, government office/institute & 17 & 10.76 \\
\hline Public enterprise, government office/ institute, micro enterprise & 2 & 1.27 \\
\hline Public enterprise, government office/ institute, micro enterprise, NGO & 2 & 1.27 \\
\hline Public enterprise, micro enterprise & 2 & 1.27 \\
\hline Public enterprise, NGO & 1 & 0.63 \\
\hline privet enterprise & 3 & 1.90 \\
\hline Public enterprise, government office/institute & 6 & 3.80 \\
\hline Private enterprise, government office/ institute, micro enterprise & 1 & 0.63 \\
\hline Privet enterprise, NGO & 3 & 1.90 \\
\hline Government office institute & 20 & 12.66 \\
\hline Government office/ institute, micro enterprise & 2 & 1.27 \\
\hline Government office/ institute, NGO & 1 & 0.63 \\
\hline Government office/ institute \& micro enterprise & 1 & 0.63 \\
\hline Micro enterprise & 5 & 3.16 \\
\hline Micro enterprise, NGO & 1 & 0.63 \\
\hline NGO & 6 & 3.80 \\
\hline Total & 158 & 100.00 \\
\hline
\end{tabular}

Source: Surveyed data 2020 
Table 8. Cooperate training.

\begin{tabular}{|c|c|c|c|c|c|c|c|}
\hline & & Missed & Str. Disagree & disagree & Neutral & Agree & Str. Agree \\
\hline \multirow{2}{*}{ Before cooperative training I was provided with basic skills } & $\mathrm{F}$ & 13 & 5 & 1 & 10 & 52 & 148 \\
\hline & $\%$ & 5.68 & 2.18 & 0.44 & 4.37 & 22.71 & 64.63 \\
\hline I was actively involved in usual working/ production processes & $\mathrm{F}$ & 12 & 4 & 5 & 10 & 46 & 152 \\
\hline \multirow{2}{*}{ I gained an overreaching understanding about the working process } & $\mathrm{F}$ & 15 & 7 & 5 & 15 & 49 & 138 \\
\hline & $\%$ & 6.55 & 3.06 & 2.18 & 6.55 & 21.40 & 60.26 \\
\hline Cooperative training was related to my training area. & $\mathrm{F}$ & 17 & 4 & 11 & 8 & 42 & 147 \\
\hline \multirow{2}{*}{ Industry trainer was assigned from the company } & $\mathrm{F}$ & 19 & 29 & 37 & 27 & 30 & 87 \\
\hline & $\%$ & 8.30 & 12.66 & 16.16 & 11.79 & 13.10 & 37.99 \\
\hline \multirow{2}{*}{$\begin{array}{l}\text { The industry trainer was well qualified and committed to assist my } \\
\text { performance }\end{array}$} & $\mathrm{F}$ & 15 & 12 & 30 & 28 & 43 & 101 \\
\hline & $\%$ & 6.55 & 5.24 & 13.10 & 12.23 & 18.78 & 44.10 \\
\hline \multirow{2}{*}{ Feedback about my performance was continuously provided } & $\mathrm{F}$ & 13 & 9 & 16 & 24 & 47 & 120 \\
\hline & $\%$ & 5.68 & 3.93 & 6.99 & 10.48 & 20.52 & 52.40 \\
\hline \multirow{3}{*}{$\begin{array}{l}\text { College and company trainers were regularly tested my } \\
\text { competences } \\
\text { I gained knowledge, skills and attitudes required in the world of } \\
\text { work. }\end{array}$} & $\mathrm{F}$ & 11 & 14 & 18 & 25 & 35 & 126 \\
\hline & $\%$ & 4.80 & 6.11 & 7.86 & 10.92 & 15.28 & 55.02 \\
\hline & $\%$ & 5.68 & 6.55 & 2.62 & 5.24 & 14.85 & 65.07 \\
\hline
\end{tabular}

Source: Surveyed data 2020

The opinions of graduates were collected based on measuring parameters related to the cooperative trainings listed in table 9. It was found that $87.51 \%$ were above medium value i.e. as per the parameters many respondents agreed. They confirmed that sufficient basic skills were provided before cooperative trainings, actively participating in production processes, gained sufficient understanding of overall processes in the companies, cooperative trainings were relevance to training areas, industry well qualified trainers were assigned, assessments were provided with feed backs. Of courses if all things are fulfilled during cooperative trainings in the college, it means that appropriate training is provided. But the reality on the ground doesn't show this fact. This finding contradicts, the action research undertaken by Tamiru et al. (2019). To mention a few, the companies were irrelevant and trainees were not allowed to involve directly in the production processes. Hence, in the future the questionnaires needed to be filled curiously with the assistance of the enumerators.

Table 9. Type of trainings that make trainers more competent.

\begin{tabular}{lll}
\hline Variables & Frequency & Percent \\
\hline Practical training in the college & 58 & 28.15 \\
Cooperative training in company & 5 & 2.43 \\
Both are equally important & 75 & 36.41 \\
Both are equally unimportant & 68 & 33.01 \\
Total & 206 & 100.0 \\
\hline
\end{tabular}

Source: Surveyed data 2020

The opinion of the graduates has contribution to conduct the tracer study of the graduates for these purposes the data collected from sampled respondents. The opinions of the graduates were also surveyed to know training delivery mechanisms that can enables trainees to acquire occupational skills. In view of this it was found that those replied practical training in the college were $28.15 \%$ (58), cooperative training in company were $2.43 \%(5)$, both practical training in the college and cooperative training in company were $36.41 \%$ (75) and both are equally unimportant were $33.01 \%$ (68). This finding shows the cooperative training was rated list among the four alterative provided to rate.

\subsection{Employer Organization}

\subsubsection{Classification of Employer Organization}

Category of employer organization by sector

In Ethiopian there is different sector that accept the graduates of Holeta Polytechnic College such as agriculture, Industry, construction, manufacturing and services sectors. Currently Holeta Polytechnic College were employed by agriculture, Industry, construction, manufacturing and services sectors. As indicated in the table 10 below, Employer organization who currently employed TVET graduates are purposively selected and 31 of them were contacted. From 31 employer organization 25 of them which is $80.6 \%$ are Service (governmental and nongovernmental organization who are rendering services) whereas $12.9 \%$ are manufacturing and $3.2 \%$ are construction and agriculture.

Table 10. Category of employer organization by sector.

\begin{tabular}{lll}
\hline Sector & No & \% \\
\hline Agriculture & 1 & 3.2 \\
Service & 25 & 80.6 \\
Construction & 1 & 3.2 \\
Manufacturing & 4 & 12.9 \\
Total & 31 & 100 \\
\hline
\end{tabular}

Source: Surveyed data 2020

Type of organization

The statistics in the Figure 3 shows further detail in the type and ownership of the employer. The data show that $42 \%$ of the employer organizations are public organization, $26 \%$ of them are Share companies, $26 \%$ of them privately owned organization and the rest $6 \%$ is partnership. 


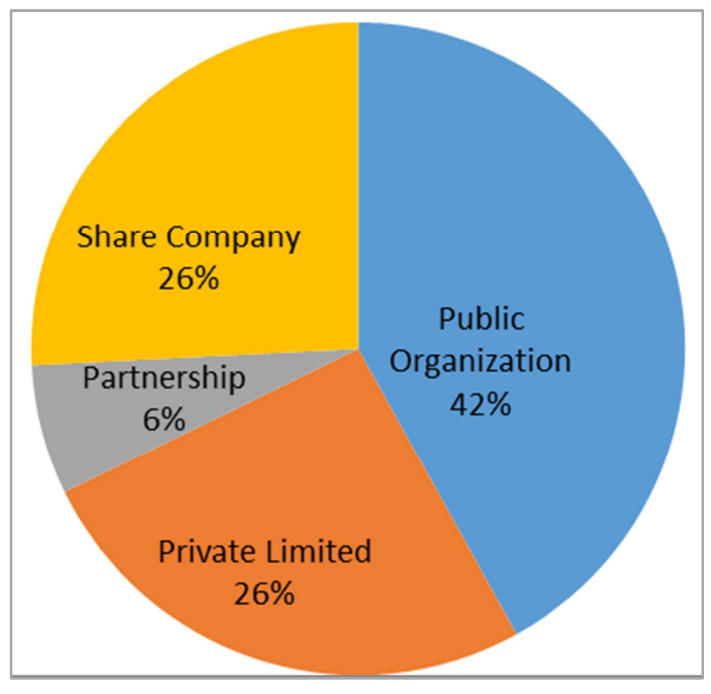

Source: Surveyed data 2020

Figure 3. Types of employing organization.

\subsubsection{Employers Satisfaction Level with Competence of Graduates}

Employer organizations' perception to the competence of the TVET graduates was assessed. The question was posed to managers to know how they evaluate the graduates' competence. Out of 27 organizations $55.56 \%$ of them evaluated TVET graduates on the medium value. On the other hand, only $22.22 \%$ and $11.11 \%$ of them evaluated the graduates' competence as satisfactory and very satisfactory, respectively. The organizations who feel that our graduate's competence below medium value was $11.11 \%$ (i.e., $7.40 \%$ and $3.71 \%$ not satisfactory and not very satisfactory, respectively). In general, it was found that $77.78 \%$ of organizations under study rated the competencies of our TVET graduates on middle value and above satisfaction level.
Table 11. Satisfaction of employer organizations on the competences of TVET graduates.

\begin{tabular}{lll}
\hline Satisfaction Level & Frequency & Percent \\
\hline Not very satisfactory & 1 & 3.71 \\
Not Satisfactory & 2 & 7.40 \\
Neutral & 15 & 55.56 \\
Satisfactory & 6 & 22.22 \\
Very Satisfactory & 3 & 11.11 \\
Total & 27 & 100.0 \\
\hline
\end{tabular}

Source: Surveyed data 2020

The dissatisfactions observed on TVET graduates by their employers were displayed as follow:

The graduate needs additional training on their work.

It is good to work on work ethics (Professional ethics).

Graduates have low level of knowledge.

The theoretical part has to be supplemented by practice.

What is learned in the class and the real-world work has no any connection.

Education do not fit with his work.

There is ups \& downs in performance of workers.

Much emphasis has to be given to practical work.

Employers' Satisfaction on TVET graduates on the bases of quality parameters.

Employer organizations were also asked in order to rate TVET graduates hired in their organization based on the different quality parameters. As illustrated in the table 12 a Likert scale with value of 1 to 5 in which 1 stands for Very low, and 5 very high were given for the respondents to measure TVET alumni against the given quality parameters. As indicated in the table 12 below the mean value of Employers' satisfaction varies from 4.14 (Honesty) to 3.37 (ability to work without constant supervision). Employers' satisfaction with the related to quality parameters have mean score above 3.37 . The result shows that employers are satisfied to graduates' performance.

Table 12. Employers' Satisfaction on TVET graduates on the bases of quality parameters.

\begin{tabular}{|c|c|c|c|c|c|c|c|}
\hline & 1 & 2 & 3 & 4 & 5 & $\mathbf{N}$ & Mean \\
\hline Loyalty to the organization & 2 & 0 & 8 & 9 & 10 & 29 & 3.86 \\
\hline Strong professional skills & 0 & 2 & 11 & 9 & 7 & 29 & 3,72 \\
\hline Team work & 0 & 0 & 7 & 15 & 6 & 28 & 3.96 \\
\hline Good Work ethics & 1 & 0 & 5 & 14 & 8 & 28 & 4 \\
\hline Honesty & 0 & 1 & 6 & 9 & 12 & 28 & 4.14 \\
\hline Work attitude & 1 & 1 & 5 & 13 & 9 & 29 & 3.65 \\
\hline Ability to work without constant supervision & 1 & 4 & 12 & 7 & 5 & 29 & 3.37 \\
\hline Problem Solving Skills & 1 & 2 & 11 & 11 & 4 & 29 & 3.51 \\
\hline Good Communication skills & 0 & 4 & 5 & 13 & 7 & 29 & 3.79 \\
\hline Strong technical literacy skills \& understanding & 1 & 2 & 12 & 8 & 6 & 29 & 3.65 \\
\hline Strong numerical skills \& Understanding & 0 & 4 & 5 & 14 & 6 & 29 & 3.75 \\
\hline Willingness to learn new things $\&$ creativity & 0 & 4 & 5 & 13 & 7 & 29 & 3.79 \\
\hline Learn from mistakes & 1 & 1 & 8 & 13 & 6 & 29 & 3.75 \\
\hline
\end{tabular}

Source: Surveyed data 2020

\subsubsection{The Skill Gaps of TVET Graduates as Observed by Employers}

Employers are satisfied with the performance of TVET Graduates but a few employer organizations witnessed the skill gaps seen among the TVET graduates as it is summarized in table 13. 
Table 13. Skill gable of TVET graduates.

\begin{tabular}{lll}
\hline Qualifications & Level & Skill Gap \\
\hline Secretary Science and office management & I to II & $\begin{array}{l}\text { Lack of communication skill } \\
\text { Poor problem-solving ability } \\
\text { Lack of confidence to develop skills } \\
\text { Knowledge Gap on Anatomy \& Physiology } \\
\text { Ethical Problems }\end{array}$ \\
Advanced Animal Health Service & IV & $\begin{array}{l}\text { Independence } \\
\text { Entrepreneurship }\end{array}$ \\
Mechanics & & $\begin{array}{l}\text { Market Linkage } \\
\text { Soft \& Hard Skills }\end{array}$ \\
Clinical Lab Technician & I to II & Practical Work \\
Entrepreneurship & Weak attitude to be self-employment \\
\hline
\end{tabular}

Source: Surveyed data 2020

\subsection{Employed Graduates}

\subsubsection{Distribution of Employed Graduates in Sectors and Type of Employer Organization}

As discussed under section two of this document the total graduates surveyed were 45 . Their distribution in sector was shown in table 14. The percentage of employed rate from highest to list is Manufacturing, agriculture, trade and workers and social affairs are 35.6\%, 26.7\%, $13.3 \%$ and $4.4 \%$, respectively. The sector/s that absorbed $20 \%$ of the employees were not specified. This is partly due to the fact that some graduates are hired out of their occupation. In terms of employer organization private enterprises hold the highest positions (46.7\%). Government organizations and NGO hold the second and third positions in hiring TVET graduates.

Table 14. Graduate's employer organization by sector.

\begin{tabular}{llll}
\hline & & Frequency & Percent \\
\hline \multirow{4}{*}{ Sector } & Agriculture & 12 & 26.7 \\
& Manufacturing & 16 & 35.6 \\
& Workers \& Social Affairs & 2 & 4.4 \\
& Trade & 6 & 13.3 \\
& Other & 9 & 20.0 \\
& Total & 45 & 100.0 \\
& Public Enterprise & 1 & 2.2 \\
Type of & Private Enterprise & 21 & 46.7 \\
& Government & 17 & 37.8 \\
& NGO & 3 & 6.7 \\
& Others & 3 & 6.7 \\
& Total & 45 & 100.0 \\
\hline
\end{tabular}

Source: Surveyed data 2020

Table 15. Job placement of TVET graduates.

\begin{tabular}{lll}
\hline Variable & Frequency & Percent \\
\hline Assistance by TVET institution & 2 & 4.76 \\
Relation during cooperative training & 4 & 9.53 \\
Contacting companies directly & 30 & 71.43 \\
Public advertisement such as internet, & 5 & 11.90 \\
newspaper, radio, TV, advertisement boards & 1 & 2.38 \\
Other & 42 & 100.0 \\
Total & & \\
\hline
\end{tabular}

Source: Surveyed data 2020

\subsubsection{Job Placement of TVET Graduates}

Even though TVET graduates were expected to be selfemployer, many graduates look for job opportunities in private organization, government and non-government institutions. Among 81 organization visited during the field study, 31 of them have employed 42 TVET graduates. The graduates were asked how they got the job they are currently engaged in. Their response is illustrated in table 15.

The data showed that two-third of the graduates secured the job by directly contacting employees. The role of TVET institutions in job placement is found very minimal. Similarly, though cooperative training is expected to play positive role in paving the way for future employment opportunity, less than $10 \%$ of the employed graduates secured job in this way which calls for reconsideration of TVET strategy in terms of Cooperative training.

Relevance of graduates' current job was assessed in relation to their area of qualification; i.e., employed graduates were asked whether they were employed on jobs related to their qualification/ occupation or not. In this regard, out of 42 graduates $50 \%$ were employed on the related position and $50 \%$ were employed to the position which is irrelevant to their field of study (Table 16).

Those employed in unrelated jobs put their reasons as follow.

Vacancy didn't fit with his/her qualification.

Lack required work experience in his/he area of study

Table 16. Relevance of graduate's qualification.

\begin{tabular}{lll}
\hline Variables & Frequency & Percent \\
\hline Yes & 21 & 50 \\
No & 21 & 50 \\
Total & 42 & 100.0 \\
\hline
\end{tabular}

Source: Surveyed data 2020

Table 17. On job training provided to graduates by organization.

\begin{tabular}{lll}
\hline Variables & Frequency & Percent \\
\hline Yes & 30 & 68.19 \\
No & 14 & 31.81 \\
Total & 44 & 100.0 \\
\hline
\end{tabular}

Source: Surveyed data 2020

Some graduates were hired before they joined the college and still have worked on their previous position in their 
organization after graduation.

Others have been employed on jobs which has indirect relation with the graduates' field of study.

The employed graduates also asked whether they had got on job training or not. Out of 45 respondents those who said 'yes' were 68.19\% and 'no' were 31.81\% (Table 17). The respondents stated that on job trainings were given for them to familiarize with working machine, for safety precautions of work places, to enhance their productivity, efficiency and effectiveness through KAIZEN trainings.

Table 18. Competency aspects important for employability of graduates.

\begin{tabular}{|c|c|c|c|c|c|c|c|c|c|c|c|c|}
\hline \multirow{2}{*}{ Determinant factors } & \multicolumn{2}{|c|}{ Missed } & \multicolumn{2}{|l|}{1} & \multicolumn{2}{|l|}{2} & \multicolumn{2}{|l|}{3} & \multicolumn{2}{|l|}{4} & \multicolumn{2}{|l|}{5} \\
\hline & $\mathbf{F}^{*}$ & $\%$ & $\mathbf{F}$ & $\%$ & $\mathbf{F}$ & $\%$ & $\mathbf{F}$ & $\%$ & $\mathbf{F}$ & $\%$ & $\mathbf{F}$ & $\%$ \\
\hline My professional qualification was demanded in the market & 3 & 6.7 & 4 & 8.9 & 2 & 4.4 & 4 & 8.9 & 16 & 35.6 & 16 & 35.6 \\
\hline Participation in cooperative training & 3 & 6.7 & 4 & 8.9 & 4 & 8.9 & 2 & 4.4 & 17 & 37.8 & 15 & 33.3 \\
\hline Knowledge competency & 3 & 6.7 & 2 & 4.4 & 2 & 4.4 & 3 & 6.7 & 20 & 44.4 & 15 & 33.3 \\
\hline Skill competency/ & 4 & 8.9 & 3 & 6.7 & 2 & 4.4 & 6 & 13.3 & 15 & 33.3 & 15 & 33.3 \\
\hline Attitude competency & 3 & 6.7 & 3 & 6.7 & 3 & 6.7 & 2 & 4.4 & 11 & 24.4 & 23 & 51.1 \\
\hline Social and individual relationship & 7 & 15.6 & 1 & 2.2 & 3 & 6.7 & 2 & 4.4 & 15 & 33.3 & 17 & 37.8 \\
\hline MAX & 7 & 16 & 4 & 8.9 & 4 & 8.9 & 6 & 13 & 20 & 44.4 & 23 & 51.1 \\
\hline MIN & 3 & 6.7 & 1 & 2.2 & 2 & 4.4 & 2 & 4.4 & 11 & 24.4 & 15 & 33.3 \\
\hline $\mathrm{SD}$ & 1.5 & 3.3 & 1.1 & 2.4 & 0.7 & 1.7 & 1.5 & 3.3 & 2.7 & 6.0 & 2.9 & 6.3 \\
\hline
\end{tabular}

$\mathrm{F}^{*}$ stands for frequency

Source: Surveyed data 2020

Table 19 shows that findings on shortcomings of factors like training of practical skills, transfer of theoretical knowledge, teaching/training methodology, commitment of teaching staff, training materials/ equipment and preparation of MC and TTLM that were measured with Likert scale ranged from 1 to 5 ( $1=$ Not at all, $2=$ To a little extent, $3=$ To some extent, $4=$ To a great extent; $5=$ To a very great). At average the highest scale laid on number two (2) i.e., in line with factors mentioned above the dissatisfaction of the respondent is low.

Table 19. Evaluation of employed graduates on training quality determinant factors.

\begin{tabular}{|c|c|c|c|c|c|c|c|c|c|c|c|c|c|c|}
\hline \multirow{2}{*}{ Determinant factors } & \multicolumn{2}{|l|}{$\mathbf{0}$} & \multicolumn{2}{|l|}{1} & \multicolumn{2}{|l|}{2} & \multicolumn{2}{|l|}{3} & \multicolumn{2}{|l|}{4} & \multicolumn{2}{|l|}{5} & \multicolumn{2}{|c|}{ Total } \\
\hline & No & $\%$ & No & $\%$ & No & $\%$ & No & $\%$ & No & $\%$ & No & $\%$ & No & $\%$ \\
\hline Training of practical skills & 9 & 20 & 3 & 6.7 & 21 & 46.7 & 6 & 13.3 & 4 & 8.9 & 2 & 4.4 & 45 & 100 \\
\hline Transfer of theoretical knowledge & 9 & 20 & 7 & 15.6 & 16 & 35.6 & 7 & 15.6 & 4 & 8.9 & 2 & 4.4 & 45 & 100 \\
\hline Commitment of teaching staff & 11 & 24.4 & 5 & 11.1 & 20 & 44.4 & 5 & 11.1 & 2 & 4.4 & 2 & 4.4 & 45 & 100 \\
\hline Training materials/ Equipment & 9 & 20 & 5 & 11.1 & 16 & 35.6 & 5 & 11.1 & 8 & 17.8 & 2 & 4.4 & 45 & 100 \\
\hline Preparation of MC and TTLM & 11 & 24.4 & 7 & 15.6 & 14 & 31.1 & 7 & 15.6 & 2 & 4.4 & 4 & 8.9 & 45 & 100 \\
\hline
\end{tabular}

Source: Surveyed data 2020

Table 20. 2019 E.C. Job placement rate of Holeta Polytechnic College by organizations.

\begin{tabular}{|c|c|c|c|c|c|c|}
\hline \multirow{2}{*}{ Employer } & \multicolumn{2}{|l|}{ Male } & \multicolumn{2}{|l|}{ Female } & \multicolumn{2}{|c|}{ Total } \\
\hline & No & Percent & No & Percent & No & Percent \\
\hline Self-Employment & 10 & 13.0 & 1 & 1.3 & 11 & 14.29 \\
\hline Gov't Employment & 20 & 26.0 & 7 & 9.1 & 24 & 31.17 \\
\hline NGO employment & 1 & 1.3 & 0 & 0.0 & 1 & 1.30 \\
\hline Private enterprise employment & 33 & 42.9 & 5 & 6.5 & 38 & 49.35 \\
\hline Total & 64 & 83.1 & 13 & 16.9 & 77 & 100.00 \\
\hline
\end{tabular}

Source: Surveyed data 2020

Table 21. Summery of Total Graduates and employed graduates in sector and occupation.

\begin{tabular}{|c|c|c|c|c|c|c|c|c|c|c|c|c|c|}
\hline \multirow{3}{*}{ Sector } & \multirow{3}{*}{ Occupation } & \multicolumn{6}{|c|}{ Total graduates } & \multicolumn{6}{|c|}{ Employed graduates } \\
\hline & & \multicolumn{2}{|c|}{ Male } & \multicolumn{2}{|c|}{ Female } & \multicolumn{2}{|c|}{ Total } & \multicolumn{2}{|c|}{ Male } & \multicolumn{2}{|c|}{ Female } & \multicolumn{2}{|c|}{ Total } \\
\hline & & No & $\%$ & No & $\%$ & No & $\%$ & No & $\%$ & No & $\%$ & No & $\%$ \\
\hline \multirow{4}{*}{ Agriculture } & AAHC & 47 & 19.75 & 12 & 5.04 & 59 & 24.79 & 36 & 15.13 & 4 & 1.68 & 40 & 16.81 \\
\hline & APMM & 28 & 11.76 & 16 & 6.72 & 44 & 18.49 & 7 & 2.94 & 4 & 1.68 & 11 & 4.62 \\
\hline & CPMM & 12 & 5.04 & 7 & 2.94 & 19 & 7.98 & 3 & 1.26 & 1 & 0.42 & 4 & 1.68 \\
\hline & NRCUM & 45 & 18.91 & 33 & 13.87 & 78 & 32.77 & 7 & 2.94 & 1 & 0.42 & 8 & 3.36 \\
\hline Construction & BEI & 11 & 4.62 & 0 & 0.00 & 11. & 4.62 & 8 & 3.36 & 0 & 0.00 & 8 & 3.36 \\
\hline IT & ITSS & 0 & 0.00 & 4 & 1.68 & 4 & 1.68 & 0 & 0.00 & 1 & 0.42 & 1 & 0.42 \\
\hline Total & & 155 & 65.13 & 83 & 34.87 & 238 & 100.00 & 64 & 26.89 & 13 & 5.46 & 77 & 32.35 \\
\hline
\end{tabular}

Source: Surveyed data 2020 


\subsubsection{Job Placement Rate of Holeta Polytechnic College}

VGC team of HPT College made phone calls for 238 (Male $=155$ and Female $=83$ ) to know the where about of HPC graduates of 2019. It was possible to get only 138 graduates on phone call. The team couldn't find the 100 graduates because either the graduates out of telephone network, or switched off their phone or the phone numbers they gave to VGC was wrong. The VGC team assured that out of 138 contacted through call phone only 76 (Male=64 and Female=13) graduates were employed. These 76 employed have been hired in private enterprises, government organizations, NGOs or few started their own business. The remaining 61 graduates are unemployed. Knowing the employment status of those whose phone is not functional needs further investigation. The largest employer of our graduates was private enterprise (49.35\%), followed by government, self-employment, whereas the list employers were NGOs (Table 20).

As illustrated in Table 21 only $32.35 \%$ were employed out of 238 graduates. Among the employed graduates, $16.81 \%$ is AAHC, followed by APMM with $4.62 \%$ and NRCUM \& BEI are $3.36 \%$.

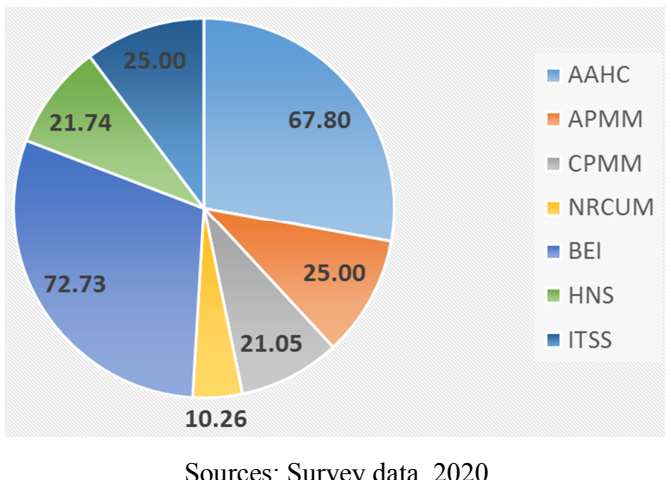

Figure 4. Graduate's occupation standard.
But the percentage of graduates when calculated with the specific number of graduates each occupation, the $1^{\text {st }}$ is BEI $(72.73 \%)$. The $2^{\text {nd }}$ is AAHC $(67.80 \%), 3^{\text {rd }}$ is CPMM $(21.05 \%), 4^{\text {th }}$ is APMM, $5^{\text {th }}$ is APMM $(25 \%)$ and $\operatorname{ITSS}(25 \%)$, the last is HNS $(21.74 \%)$ and the list is NRCUM (10.26\%).

\subsection{Unemployed Graduates}

\subsubsection{Statistics of Unemployed Graduates by Their Occupation}

The Ethiopian Technical and Vocational Education and Training (TVET) system has been supplying skilled manpower necessary for the development of the national economy by making the graduates competent enough either to be selfemployed or waged employed entrepreneur. To the contrary, there are graduates of HPTC who are not yet employed.

Under this topic TVET graduates who are not yet employed were also traced. Out of the total TVET graduate of Holeta Polytechnic College by the year 2019 E.C, 51 of them are under the Holeta Catchment area; 16 of them has gotten employment, 12 of them unemployed and the other 23 of them the telephone they gave is not functioning. Data gathered through telephone interview from 12 unemployed graduates was analyzed.

\subsubsection{Gender and Martial Status of the Unemployed Graduate}

Gender: As indicated in the table 22, the gender proportion of the unemployed graduate is equal; $50 \%$ of unemployed respondents were male and $50 \%$ were female.

Marital Status: $11(91.67 \%)$ are single and $1(8.33 \%)$ are married.

Age: 7 of them which is $58.33 \%$ are between age of $20-23$ years; 2 of them (16.67\%) are below age of 19; and $3(25 \%)$ are above 2429 years old.

Table 22. Gender, Age and Martial Status of Respondents.

\begin{tabular}{|c|c|c|c|c|c|c|c|c|c|c|}
\hline & \multicolumn{3}{|c|}{ Gender } & \multicolumn{3}{|c|}{ Marital Status } & \multicolumn{4}{|c|}{ Age category in years } \\
\hline & Male & Female & Total & Married & single & Total & $<19$ & $20-23$ & $>24$ & Total \\
\hline No & 6 & 6 & 12 & 1 & 11 & 12 & 2 & 7 & 3 & 12 \\
\hline$\%$ & 50 & 50 & 100 & 8.33 & 91.67 & 100 & 16.67 & 58.33 & 25 & 100 \\
\hline
\end{tabular}

Source: Surveyed data August 2020

Table 23. Unemployed graduates by their field/Occupation.

\begin{tabular}{lll}
\hline & No & \% \\
\hline AAHS-IV & 1 & 8.33 \\
CPMM-IV & 3 & 25 \\
NRCUM-IV & 5 & 41.67 \\
HNS-IV & 2 & 16.67 \\
ITSS-II & 1 & 8.33 \\
Total & 12 & 100 \\
\hline
\end{tabular}

Source: Surveyed data August 2020

As indicated in the table 23 out of 12 unemployed respondents $5(41.67 \%)$ of them are NRCUM-IV and $3(25 \%)$ of them are CPMM-IV and $2(16.67 \%)$ of them are HNS-IV and the rest are AAHS-IV, ITSS-II.

\subsubsection{Current Status of Unemployed Graduate}

Table 24. Unemployed graduate Activities.

\begin{tabular}{lll}
\hline & No & \% \\
\hline Other Training & 2 & 14.3 \\
Serving the family & 1 & 7.1 \\
Searching for job & 6 & 42.9 \\
Other & 3 & 35.7 \\
Total & 12 & 100.0 \\
\hline
\end{tabular}

Survey Data: August 2020

The statistics in the Table 24 shows that $42.9 \%$ of them are searching jobs; $14.3 \%$ of them are started other training, $7.1 \%$ 
is serving family and $35.7 \%$ of them are doing other things like (Continued education, working for charity and searching for vacancy) while are searching for job.

\subsubsection{Time Taken to for Searching Job}

Regarding the period of time to search for job 11 of them $(78 \%)$ are searching for job for one years, 1 graduate $(7 \%)$ has been searching for 7 months, 2 (14\%) of them do not responded.

\subsubsection{Methods Employed to Search for Job}

The statistics in the Table 25 shows that $50 \%$ of the unemployed graduates using mass media; $28.6 \%$ of them are using direct contacts to Governmental and non-governmental organization and the rest $21.4 \%$ are employing TVET to search job

Table 25. Methods employed to search for job.

\begin{tabular}{lll}
\hline Methods to search for jobs & No & Percent \\
\hline Public advertisement such as internet, newspaper, & 5 & 50.0 \\
radio, TV, advertisement boards & & \\
Direct contact GO \& NGOS & 4 & 28.6 \\
With help of TVET College & 3 & 21.4 \\
Total & 12 & 100.0 \\
\hline
\end{tabular}

Surveyed date August 2020

\subsubsection{Actions to Get Employment}

Box1: Action taken by the unemployed graduates to get employment

What are actions you are taking to get Employment either as self-employment tor paid employment?

I am doing my best to searching for vacancy

Organized on Mushroom production and failed to continue because of lack of collateral to get money.

Started the process to start but the process from the kebele is taking time

Not doing any thing

\subsubsection{Relevance of Field of Study for Application}

The statistics in the Figure 5 shows that 50 of the respondents are applying for vacancy which is relevant to their field of study and the rest 50\% are applying for field which are irrelevant.

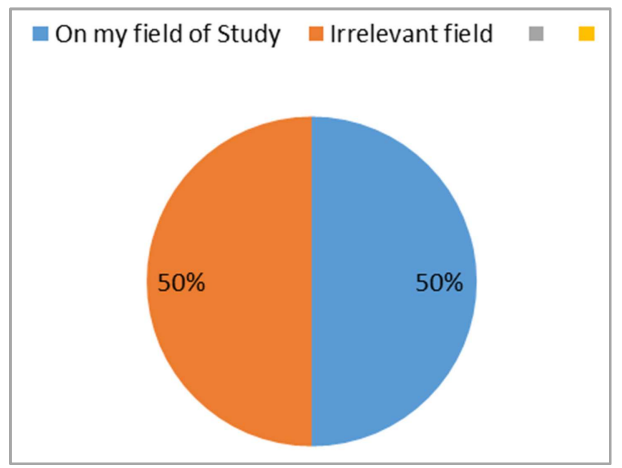

Source: Survey data, 2020

Figure 5. Relatedness of graduates to area of employed.
Reason for applying for irrelevant job vacancy

Graduates are applying to vacancy which is irrelevant to their field of study because:

No demand for their field

Bureaucracy to be employed

Excess supply in the field

Investors not yet started

What were your major obstacles for your not to be employed?

Table 26. Obstacle for being unemployed.

\begin{tabular}{ll}
\hline Field of Study & Obstacles \\
\hline \multirow{2}{*}{ NRUC-L-IV } & Bureaucracy \\
& More supply in the field \\
& Bureaucracy \\
CPMM-IV & More supply in the field \\
& Work experience is asked \\
& Far away/distance \\
\hline
\end{tabular}

\section{Conclusions}

This study was under taken to trace back the where about of the graduates of TVET institutes after one year of their graduation. This study catchment area is specific to Holeta Town and Walmara district. The document includes the study result of four type of populations (graduates, employer, employed graduates and unemployed graduates). The base line survey is solely done on HPTC's graduates which are total of 229 graduates (182 male and 87 female). The survey of employed graduates was taken place with labor market need assessment (LMNA) for 2013 data collection on the private enterprises, government and non-government organizations. which were surveyed alongside

The total number 2019 graduates employed in these organization were 45 out of which 42 graduates $50 \%$ (21) were employed on the related position where as $50 \%$ (21) were employed to the position which is irrelevant to their field of study which indicated number of graduates employed in the related to qualification and unrelated to qualification is proportional. The number of employer organization are 31 . They were also surveyed simultaneously with LMNA and employed graduates. The study on unemployed graduates was limited to graduates of HPTC which were found in the study catchment area. Out of 51 graduates found in Holeta and Walmara district only 14 unemployed graduates filled the survey questionnaires $14.3 \%$ (2) continued their degree program while other are still searching for the job. The study revealed that lack of experience, existing bureaucracy, saturation of the occupation of the graduates are the main obstacles to get jobs. The telephone follows up enabled the researcher to identify the status of 138 graduates out which 77 found to be employed during the survey period. This figure is $32.35 \%$ of the total graduates. $57.65 \%$ has not yet employed and hence they are work seeker backlogs.

\section{Recommendations}

For the effectiveness of the tracer study the researchers 
recommends the following points.

Table 27. Recommendation based on the finding.

\begin{tabular}{|c|c|c|c|}
\hline No & Action to taken & Responsible body & Implementation mechanism \\
\hline & $\begin{array}{l}\text { Building the data base of all graduates to } \\
\text { obtain at single points at all level TVET } \\
\text { structures }\end{array}$ & $\begin{array}{l}\text { FTA } \\
\text { TVET Bureau } \\
\text { Town/Aanaa TVET offices } \\
\text { HPC, training centers }\end{array}$ & $\begin{array}{l}\text { Putting the data of all graduates in easily accessible way on website } \\
\text { The data of all graduates in easily accessible way on website } \\
\text { In excel or in other suitable data base software } \\
\text { In excel or in other suitable data base software }\end{array}$ \\
\hline & $\begin{array}{l}\text { Networking all TVET Colleges in order to } \\
\text { share the data of their graduates. } \\
\text { Sending the graduates to their }\end{array}$ & $\begin{array}{l}\text { FTA, TVET Bureau, Zonal } \\
\text { TVET offices }\end{array}$ & Creating common data platforms \\
\hline & $\begin{array}{l}\text { Town/Aanaa TVET to create fertile ground } \\
\text { for tracer study at their locality }\end{array}$ & HPC, training centers & Through letter \\
\hline & Creating graduate alumni association & HPC, training centers & $\begin{array}{l}\text { Through trainee's council and VGC team before the graduates leave } \\
\text { the college }\end{array}$ \\
\hline & Improving the data collection tool & FTA, TVET Bureau & $\begin{array}{l}\text { Involving TVET in questionnaire development and pilot testing } \\
\text { before utilization }\end{array}$ \\
\hline & $\begin{array}{l}\text { Organizing the TVET in SME before } \\
\text { living the college }\end{array}$ & HPC, training centers & Delivering life skill training before graduations, preparing projects \\
\hline & Saving money for self-employment & Trainees & Starting at their entry of the college until completion of the training. \\
\hline & Delivering work place & $\begin{array}{l}\text { Town/Aanaa } \\
\text { administration }\end{array}$ & $\begin{array}{l}\text { Through board facilitation the working place should be prepared for } \\
\text { the graduates }\end{array}$ \\
\hline & Finding employer organization & HPC, training centers & $\begin{array}{l}\text { Identifying and communicating potential employer organizations. } \\
\text { through VGC facilitation }\end{array}$ \\
\hline
\end{tabular}

\section{References}

[1] Getachew Tefera, A Tracer Study on (2011 - 2013) Debre Berhan University Graduates Integration in to the World of Work, International Journal of Secondary Education. Vol. 6, No. 2, 2018, pp. 37-45. doi: 10.11648/j.ijsedu.20180602.13.

[2] Heidemann L. (2010). Introduction, Preparation and Conduct of Tracer Surveys; Practical Aspects of the Project Implementation. Kassel: INCHER-Kassel.

[3] Herrmann D., Dilger B. and M. Junghanns. (2010). Specialized Questionnaires in Graduate Tracer Studies; Demand, Development and Back Channeling Results. Koln: University of Cologne.

[4] Schomburg H. (2003). Handbook for Graduate Tracer Studies. Kassel: Centre for Research on Higher Education and Work, University of Kassel.

[5] Teichler U. (1998). "The Transition from Higher Education to Employment in Europe", Higher Education in Europe, Vol. XXIII, No. 4.

[6] Teichler U. (1999). "Research on the Relationships between Higher Education and the World of Work: Past Achievements, Problems and New Challenges", Higher Education, Vol. 38, pp. 169-190.

[7] Teichler U. (2000). "Graduate Employment and Work in Selected European Countries", European Journal of Education, Vol. 35 pp. 2.
[8] Teichler U. (2003). "The Future of Higher Education and the Future of Higher Education research", Tertiary Education and Management, Vol. 9: pp. 171-185.

[9] Teichler U. (2011). Lessons to be learned from Graduates: Interpretation of the Results of Graduate Surveys. Kassel: INCHER-Kassel.

[10] Federal Technical Agency 2018, Addis Ababa University Academic Standards and Quality Enhancement Office A National Tracer Study on AAU's PhD Programs Graduates: The Cohorts of 2013 to 2018 G.C Graduates in Focus.

[11] Elias, P. \& Purcell, K. (2004). The Earnings of Graduates in their Early Careers: Researching Graduate Careers Seven Years On. Research Paper No. 4, ESRC/IER'. University of West of England \& Warwick University.

[12] Brown, P. \& Hesketh, A. (2004). The Mismanagement of Talent: Employability and Jobs in the Knowledge-Based Economy. Oxford: Oxford University Press.

[13] Keep, E. \& Mayhew, K. (2004). The Economic and Distributional Implications of Current Policies on Higher Education. Oxford Review of Economic Policy, 20, (2) 298314.

[14] Moreau, M., \& Leathwood, C. (2006). Graduates' Employment and the Discourse of Employability: A Critical Analysis. Journal of Education and Work, 19 (4), 305-24.

[15] Bridgstock, R. (2009). The Graduate Attributes We've Overlooked: Enhancing Graduate Employability through Career Management Skills. Higher Education Research \& Development, 28 (1), 31-44. 